\title{
The Effectiveness of Assertive Training Techniques and Thought- Stopping Techniques to Increase Student Assertiveness Ability
}

\author{
Siti Zahra Bulantika, Permata Sari \\ Universitas Islam Negeri Raden Intan, Lampung, Indonesia. Korespondensi: Jl. Letnan \\ Kolonel H. Endro Suratmin, Bandar Lampung, Lampung, Indonesia. \\ Email: szahrabulantika@gmail.com
}

\begin{abstract}
Article Info
History of Article

Submited November 2019

Accepted November 2019

Published November 2019
\end{abstract}

\section{Key Word}

Assertive training technique Thought-stopping technique Assertiveness ability

\begin{abstract}
In carrying out activities, not all individuals/students can behave assertively and instead choose to act non-assertive (passive), such as harboring feelings, pretending, holding differences of opinion, or vice versa by being aggressive. Allowing yourself to be non-assertive can threaten the relationship because one party will feel used by the other party, not resolve the emotional problems they face, and can cause anxiety and stress. The purpose of this study is to examine the group counseling techniques assertive training and thought-stopping to improve student assertiveness abilities. Randomized Pretest-Postest Comparison Group Design for 24 students Bandar Lampung. The instrument used was an assertive scale by Fensterheim and Baer (1980). Data analysis techniques Paired sample t-test and one-way ANOVA. The results showed that group counseling for assertive training and thought-stopping techniques was effective in increasing student assertiveness. Findings prove the success of group counseling in assertive training and thought-stopping techniques for students in the city of Bandar Lampung.
\end{abstract}

\section{Citation Info}

Bulantika, S.Z., \& Sari, P., (2019). The Effectiveness of Assertive Training Techniques and Thought-Stopping Techniques to Increase Student Assertiveness Ability. Biblio Couns: Jurnal Kajian Konseling dan Pendidikan. 2(3), 109-116. 
Biblio Couns : Jurnal Kajian Konseling dan Pendidikan | Vol. 2 No. 3 November 2019

\section{INTRODUCTION}

Adolescence is often called the Strom and drunk period, where individuals enter a period of searching for identity and are vulnerable to being influenced by various factors, especially external factors. For adolescents, the existence of friends is essential, often changing decisions and attitudes taken in dealing with problems. Teenagers also often do anything and behave following the expectations of their friends. This situation is triggered by the desire of adolescents to be recognized and accepted in the group of adolescents. Teenagers try to adjust and can survive and try to be taken in their groups, even though they have to do harmful activities (Faradita, Elita, \& Sinthia, 2018).

Teenagers often cannot behave assertively due to fear of disappointing others, a sense of solidarity with peers, fear of being disliked, and not accepted in the group. In adolescence, student assertiveness is still in the development stage, and there is a possibility of developing in a positive or negative direction (Nurtiffany, Wibowo, \& Setyowani, 2018). By having the ability to behave assertively, adolescents will more easily communicate what they want and feel and be able to reject negative conformity firmly. Asertivitas is an ability to describe what is wanted, felt, and thought to others, but while maintaining and respecting the rights and feelings of personal and other parties (Kelley, Orchowski, \& Gidycz, 2016).

The emergence of assertiveness in adolescents is due to positive self-esteem towards him. If teenagers are not assertive, they are not able to express their thoughts, feelings, and beliefs because teenagers tend not to be able to get out of problems (Yasdiananda, 2019). When undergoing daily activities, not all students can behave assertively and instead choose to act non-assertive (passive), such as harboring feelings, pretending, holding differences of opinion, or vice versa by being aggressive. Allowing yourself to be non-assertive can threaten the relationship because one party will feel used by the other party, not resolve the emotional problems they face, and can cause anxiety and stress (Furuno et al., 2018). Students who are unable to behave assertively tend to be disadvantaged by their peers. Many students cannot act assertive because they fear being shunned by their peers if they decline the invitation (Butar, 2018). Assertive behavior needs to be owned by students because it can help students in the learning process.

By behaving assertively can foster a more intimate and honest relationship, can communicate naturally and openly, confidently and calmly in the face of criticism, and provide opportunities for others to express opinions by maintaining their ideas (Sukiah, 2018). Assertiveness is the ability to communicate what is wanted honestly, not hurt others and hurt yourself, and we get what we want (Wulandari, 2018). Another understanding, assertiveness is the ability to communicate what is wanted, felt, and thought to others while maintaining and respecting the rights and feelings of personal and other parties (Kramer et al., 2016). Preliminary study at SMA N 14 Bandar Lampung, found non-assertive students.

The percentage of assertiveness ability is 47 students or $44 \%$ in the low category, 35 students or $33 \%$ of students in the medium catagory, and 23 students or $21 \%$ of students in the high category. Students who experience the situation feel afraid, shy, or hesitate to express their wishes or opinions openly, not confidence, fearful of being shunned and ignored by friends, not being assertive, or refusing friends who want to cheat (Pratiwi, 2015).

Therapies that are considered capable of training, developing, and increasing student assertiveness are assertive training techniques, further to change feelings, ways of thinking, and actions related to assertive abilities. So individuals can have confidence in their skills, and look positively at people's perceptions about himself, thought-stopping technique. Assertive training techniques are techniques that are useful to help individuals express feelings, difficulty expressing "no," showing affection, and other positive responses (Avşar \& Alkaya, 2017). The purpose of assertive training is to develop positive and negative feelings of expression, express contradictory feelings, develop behavior based on one's initiative (Kim, 2016). Farida's research using assertive training, techniques can increase self-esteem in students (Farida, Dahlan, \& Widiastuti, 2018). The use of assertive training is also proven in increasing the confidence of adolescent prisoners (Ramadhini \& Santoso, 2019). 
The usefulness of assertive training helps students who have difficulty expressing themselves in the right way, one of which can be used to overcome students who lack assertiveness abilities. The advantage of using assertive training is that students can directly practice it in the form of role-playing, so students can more easily understand the material. Roleplay is carried out in several circumstances, which can add to students' insights in increasing assertiveness. So students can find the appropriate and correct response in several situations. Furthermore, the thought-stopping technique is a skill to give instructions to yourself to stop the flow of negative thoughts through the presence of a stimulus or an extraordinary stimulus. Thought-stopping technique is a method used to overcome negative thoughts that can create problems by changing to neutral, positive, and assertive thoughts (Thahir, Rimandona, \& Bulantika, 2018).

Thought-stoping is a stopping technique that is learned by someone that can be used every time the individual wants to stop disturbing or negative thoughts and unwanted thoughts from consciousness. Thought-stopping techniques are also effectively applied to students who experience social anxiety (Bulantika, Wibowo, \& Jafar, 2018). Rostiana's research supports thought-stopping techniques to increase self-esteem in victims of bullying (Rostiana, Wibowo, \& Purwanto, 2019). The use of thought-stopping techniques because individual thoughts and beliefs can sometimes lead to negative behavior. So, problematic or negative behavior can be changed by changing his mind and feelings.

The purpose of using thought-stopping techniques is to weaken undesirable behavior by the counselee and to stop negative thoughts due to past experiences. The purpose of thought-stopping techniques is to reduce maladaptive behavior and increase assertiveness ability. Based on the explanation, the researcher tested the effectiveness of assertive training techniques and thought-stopping techniques to improve students' assertiveness skills.

\section{METHODS}

This study uses a Randomized Pretest-Postest Comparison Group Design. Subjects were taken by a purposive random sampling technique, 24 students as research subjects with non-assertive (passive) characteristics. Formation into three groups, namely group A assertive training techniques, group $\mathrm{B}$ thought-stopping techniques, and group $\mathrm{C}$ combined assertive training techniques and thought-stopping techniques. Then give the same pretest (initial test) to the experimental group. The pretest was given before the group was given treatment. After that, giving different treatments to the experimental group. Experimental group A was given treatment in the form of group counseling with assertive training techniques. Experimental group B was given group counseling treatment with thought-stopping techniques, and experimental group $\mathrm{C}$ was given treatment in the form of group counseling with assertive training techniques and thought-stopping techniques. After treatment, give the same posttest (final test) to the experimental group. Giving this posttest is done to know the difference in the results of the treatment given previously. Data collection techniques using the assertive scale by Fensterheim and Baer (1980). Hypothesis testing uses paired-sampled t-test and one-way ANOVA analysis techniques.

\section{RESULTS AND DISCUSSION}

Non-assertive conditions (passive) students after getting intervention group counseling techniques assertive training and thought-stopping showed increased assertiveness ability. Hypothesis testing uses paired-sampled t-test and one-way ANOVA tests. The Paired Sampled T-Test is used to find out the critical mean or mean differences between the pretest and posttest results in each group, then the ANOVA one-way test to determine the difference in effectiveness between group counseling services for assertive training techniques, thoughtstopping techniques, and combinations assertive training techniques and thought-stopping techniques. The results of data calculations before and after as well as differences in the effectiveness of group counseling services assertive training techniques, thought-stopping 
techniques, and a combination of assertive training techniques and thought-stopping techniques, are presented in Table 1.

Table 1. Result of Changes in Pretest and Postest Scores

\begin{tabular}{|c|c|c|c|c|c|c|c|c|c|c|}
\hline \multirow{2}{*}{ Group } & \multicolumn{2}{|c|}{ Pretest } & \multicolumn{2}{|c|}{ Postest } & \multirow{2}{*}{$t(7)$} & \multirow[t]{2}{*}{ p } & \multicolumn{2}{|c|}{ Gain Score } & \multirow[t]{2}{*}{$\mathbf{F}$} & \multirow{2}{*}{ p } \\
\hline & $M$ & $\mathrm{Sd}$ & $M$ & $\mathrm{Sd}$ & & & $M$ & Sd & & \\
\hline AT & 41,02 & 8,24 & 63,76 & 3,26 & 10,66 & $<0,01$ & 22,76 & 6,05 & 23,26 & $<0,01$ \\
\hline TS & 51,40 & 8,85 & 68,53 & 4,96 & 8,64 & $<0,01$ & 17,13 & 5,62 & & \\
\hline AT+TS & 35,52 & 8,03 & 63,39 & 5,76 & 8,14 & $<0,01$ & 27,88 & 9,71 & & \\
\hline
\end{tabular}

Note : AT: Assertive Training; TS: Thought-Stopping; AT+TS: Assertive training+ThoughtStopping

In table 1 shows the difference in the average non-assertive level of students before and after, in the assertive training group $(M=22,76, S d=6,05 ; t(7)=10,66, p<0,01)$. The results showed group counseling with effective assertive training techniques to improve student assertiveness skills. In the thought-stopping group, the difference in the average value of non-assertive levels of students before and after is $(M=17,13, S d=5,62 ; t(7)=8,64$, $p<0,01)$. The results of group thought-stopping technique counseling are effective for improving students' assertiveness abilities. Furthermore, in the combined group techniques assertive training and thought-stopping differences in the average value of non-assertive levels of students before and after $(M=27,88, S d=9,71 ; t(7)=8,14, p<0,01)$ the result is group counseling with assertive training techniques and effective thought-stopping techniques to improve students' assertiveness abilities.

ANOVA test results show differences in effectiveness between group counseling with assertive training techniques, group counseling with thought-stopping techniques, and combined assertive training group counseling techniques and thought-stopping techniques to improve student assertiveness skills $(F(2,22)=23,26, p<0,01)$. The results showed that the combined group counseling of assertive training and thought-stopping techniques was more effective than the group assertive training technique counseling and thought-stopping technique group counseling.

From the results of the study, it is known that the assertive training and thoughtstopping technique group counseling has proven to be effective in increasing students' assertiveness abilities. The results of the study are by the opinions of other researchers who show the effectiveness of assertive training techniques for students with promiscuity, student behavior changes in several aspects (Hasbahuddin, Fithrayani, \& Bakhtiar, 2019). Other research shows that assertive training techniques succeed in improving students' interpersonal skills through group guidance services (Madihah \& Susanto, 2017). Furthermore, Assertive training techniques become an alternative for counselors in increasing student confidence (Fitriyah, Dantes, \& Lestari, 2017).

Other research results also show behavioral counseling with assertive training techniques proven to improve prosocial behavior through psychodrama (Antari, Sedanayasa, \& Lestari, 2016). Assertive behavior is someone's behavior in interpersonal relationships involving emotions, feelings, thoughts, and desires. It needs in an open, firm, and honest manner without feeling anxious or tense towards others without harming yourself and others (Deliati \& Muharmi, 2019). The purpose of assertive training is to train individuals to express themselves, express what they feel, and adjust themselves to interact without anxiety because each individual has the right to express feelings, opinions, what is believed, and his attitude. Thus individuals can avoid misunderstandings in communication. 
Benefits of Assertive Training every treatment or training given certainly has various benefits for individuals who use it. The benefits of assertive training are 1) helping people who are unable to express anger and offense 2) showing excessive politeness and always encouraging others to precede it, 3) having difficulty saying "no"; having trouble expressing affection and other positive responses 4 ) feeling that he has no right to have his feelings and thoughts (Corey, 2017).

Based on this opinion, it can be concluded that assertive training is to help increase the ability to communicate what is desired, felt, and thought to others while still maintaining and respecting the rights and feelings of others. Assertive training is a behavioral therapy that is designed to develop the skills of individuals who are disturbed by anxiety with various techniques available so that the individual can have the desired assertive behavior.

Furthermore, the thought-stopping technique is one of the solutions for increasing students' assertiveness abilities. The results of other studies support the thought-stopping technique in reducing anxiety in mothers with children with special needs (Giyaningtyas \& Hamid, 2019) supported by Videbeck's opinion which states that behavioral therapy is considered useful in overcoming non-assertive behavior (passive) which causes a person to have difficulty interacting with others (Videbeck, 2008). Various types of behavioral therapy techniques are used as direct learning and practice to improve adaptive behavior or overcome maladaptive behavior, one of which is thought-stopping therapy. Also, the results of other studies prove the effectiveness of thought-stopping techniques to reduce consumer behavior in adolescents (Yuliyanawati, Wibowo, \& Japar, 2018).

Research using thought-stopping techniques shows an increase in the ability to overcome anxiety in HIV / AIDS clients before and after treatment is thought-stopping (Hidayati \& Riwayati, 2015). Furthermore, the thought-stopping technique is a therapy that can reduce the anxiety of students who are carrying out clinical practice in hospitals (Malfasari \& Erlin, 2017).

Thought-stopping refers to a group of procedures used to improve one's ability to block a series of responses cognitively. Thought-stopping trains clients to get rid of, as early as possible, any unwanted thought, usually by calling a "stop" command to interrupt unwanted thoughts. Thought-stopping is often also to help counselees who are too fixated with past events that cannot be changed (weeping for rice that has become porridge); counselee who regrets the events that might not happen; counselee bound by negative thoughts that are always repetitive and unproductive or repetitive anxiety or images that still blame themselves (Kurniawan \& Mulia, 2018).

Assertive is firmness, courage to express opinions while still respecting and sensitive to the needs of others, so finding an equally beneficial compromise. Perseverance, selfconfidence, enthusiasm, responsibility, discipline, and self-awareness possessed by assertive individuals will make it easier to achieve their goals, with the treatment of thought-stopping techniques can help unproductive control of someone or the loss of thoughts and images of oneself by way of suppress or eliminate the negative awareness by giving instructions to yourself to stop the flow of negative thoughts through the presence of shocking stimuli or stimuli, so that circumstances or feelings are not assertive (passive) in social situations can be overcome.

The results of the study concluded that group counseling with assertive training techniques and thought-stopping techniques can help students to improve students' assertiveness abilities and can be used to assist guidance and advice teachers in improving assertiveness skills, especially in SMA N 14 Bandar Lampung.

\section{CONCLUSIONS}

Allowing yourself to be non-assertive will threaten interpersonal relationships, and emotional problems will arise, lowering self-esteem can even be a "time bomb," which at any time can threaten the continuity of one's personal and social relationships and mental health, namely, the risk of anxiety and stress. The study was conducted to see the effectiveness of assertive training and thought-stopping technical group counseling to improve assertiveness 
skills in SMA N 14 Bandar Lampung students. The results showed that assertive training and thought-stopping techniques were effective in increasing students' assertiveness abilities. There are differences in the effectiveness of assertive training group counseling, thoughtstopping, and a combination of assertive training and thought-stopping techniques, and the results show that the combination of assertive training and thought-stopping techniques is more effective compared to interventions in the form of one technique. For counselors, the use of assertive training and thought-stopping techniques is expected to be able to help individuals who experience difficulties in feeling that are not appropriate in expressing them to communicate what they want, feel and think for others, the use of techniques can be applied especially in interpersonal situations.

\section{REFERENCES}

Antari, N. K. B., Sedanayasa, G., \& Lestari, L. P. S. (2016). Efektivitas Konseling Behavioral Dengan teknik Assertive Training Untuk Meningkatkan Perilaku Prososial Melalui Psikodrama Pada Siswa Kelas VIII SMP Negeri 3 Singaraja Tahun Ajaran 2015/2016. Jurnal IImiah Bimbingan Konseling Undiksha, 4(1).

Avşar, F., \& Alkaya, S. A. (2017). The effectiveness of assertiveness training for school-aged children on bullying and assertiveness level. Journal of Pediatric Nursing, 36, 186-190.

Bulantika, S. Z., Wibowo, M. E., \& Jafar, M. (2018). Group Counseling with Systematic Desensitization Techniques and Thought-Stopping Techniques to Reduce Social Anxiety. Jurnal Bimbingan Konseling, 7(2), 106-112.

Butar, M. B. (2018). Hubungan perilaku asertif dengan kenakalan remaja pada siswa SMP Negeri 6 Kota Tebing Tinggi. School Education Journal PGSD FIP Unimed, 7(4), 525532.

Corey, G. (2017). Theory and practice of counseling and psychotherapy. Nelson Education.

Deliati, D., \& Muharmi, T. (2019). Implementasi Assertive Training untuk Meningkatkan Kecerdasaan Emosional Mahasiswa pada Mata Kuliah Psikologi Pendidikan. Biblio Couns: Jurnal Kajian Konseling Dan Pendidikan, 2(1), 1-13.

Faradita, R. M., Elita, Y., \& Sinthia, R. (2018). Pengaruh Konseling Kelompok dengan Teknik Assertive Training Terhadap Kemampuan Asertivitas Siswa SMP N Kota Bengkulu. Consilia: Jurnal Ilmiah Bimbingan Dan Konseling, 1(2).

Farida, W., Dahlan, S., \& Widiastuti, R. (2018). Penggunaan Layanan Konseling Kelompok Teknik Assertive Training Untuk Meningkatkan Self Esteem Siswa. ALIBKIN (Jurnal Bimbingan Konseling), 6(2).

Fitriyah, L., Dantes, N., \& Lestari, L. P. S. (2017). Effectiveness Behavioral Coating with Modeling Techniques and Assertive Training Techniques to Increase Confidence. Bisma The Journal of Counseling, 1(1), 29-38.

Furuno, T., Nakagawa, M., Hino, K., Yamada, T., Kawashima, Y., Matsuoka, Y., ... Kawanishi, C. (2018). Effectiveness of assertive case management on repeat self-harm in patients admitted for suicide attempt: findings from ACTION-J study. Journal of Affective Disorders, 225, 460-465.

Giyaningtyas, I. J., \& Hamid, A. Y. S. (2019). Decreased Anxiety in Mother of Children With Stunting After Thought Stopping Therapy. International Journal of Nursing and Health Services (IJNHS), 2(2), 29-35. 
Hasbahuddin, H., Fithrayani, A., \& Bakhtiar, M. I. (2019). Assertive Training Untuk Mengurangi Kecenderungan Pergaulan Bebas. Indonesian Journal of Learning Education and Counseling, 1(2), 94-101.

Hidayati, E., \& Riwayati, R. (2015). Efektifitas Terapi Thought Stopping Terhadap Ansietas Klien Dengan Hiv/Aids Di Wilayah Kota Semarang. Jurnal Keperawatan Jiwa, 3(1), 5156.

Kelley, E. L., Orchowski, L. M., \& Gidycz, C. A. (2016). Sexual victimization among college women: Role of sexual assertiveness and resistance variables. Psychology of Violence, 6(2), 243.

Kim, M. (2016). Development and effects of assertiveness training applying Dongsasub training for nursing students in clinical practice. Journal of Korean Academy of Nursing, 46(4), 490-500.

Kramer, U., Pascual-Leone, A., Berthoud, L., De Roten, Y., Marquet, P., Kolly, S., ... Page, D. (2016). Assertive anger mediates effects of dialectical behaviour-informed skills training for borderline personality disorder: A randomized controlled trial. Clinical Psychology \& Psychotherapy, 23(3), 189-202.

Kurniawan, Y., \& Mulia, P. H. (2018). The Effect of Thought Stopping Therapy on The Blood and Pulse Pressures as an Anxiety Indicator of Injections. 3rd ASEAN Conference on Psychology, Counselling, and Humanities (ACPCH 2017). Atlantis Press.

Madihah, H., \& Susanto, D. (2017). Meningkatkan Kemampuan Komunikasi Interpersonal Siswa Melalui Layanan Bimbingan Kelompok Dengan Teknik Assertive Training. Jurnal Mahasiswa BK An-Nur: Berbeda, Bermakna, Mulia, 3(3), 13-17.

Malfasari, E., \& Erlin, F. (2017). Terapi Thougth Stopping (TS) untuk Ansietas Mahasiswa Praktik Klinik di Rumah Sakit. Jurnal Endurance: Kajian IImiah Problema Kesehatan, 2(3), 444-450.

Nurtiffany, T. G., Wibowo, M. E., \& Setyowani, N. (2018). Berpikir Positif dan Kepercayaan Diri Meningkat Melalui Konseling Kelompok. Indonesian Journal of Guidance and Counseling: Theory and Application, 7(4), 52-58.

Pratiwi, W. E. (2015). Pengaruh Budaya Jawa dan Harga Diri terhadap Asertivitas pada Remaja Siswa Kelas X di SMA Negeri 3 Ponorogo. Jurnal Psikologi, 3(1), 348-357.

Ramadhini, P. S., \& Santoso, M. B. (2019). Assertiveness Training untuk Meningkatkan Kepercayaan Diri Narapidana Remaja. Prosiding Penelitian Dan Pengabdian Kepada Masyarakat, 6(2), 169-180.

Rostiana, D., Wibowo, M. E., \& Purwanto, E. (2019). Keefektifan Konseling Kelompok Teknik Self Instruction dan Thought Stopping Untuk Meningkatkan Self Esteem Korban Bullying. EMPATI-Jurnal Bimbingan Dan Konseling, 6(2).

Sukiah, S. (2018). Upaya Meningkatkan Asertivitas Melalui Layanan Bimbingan Kelompok. Jurnal Global Edukasi, 1(6), 653-662.

Thahir, A., Rimandona, R., \& Bulantika, S. Z. (2018). Cinematherapy and Thought-Stopping Techniques to Reduce Social Anxiety. Proceedings International Conference of Counseling Education and Psychology (ICONCEP), 1.

Videbeck, S. L. (2008). Buku ajar keperawatan jiwa. Jakarta: Egc, 45, 2010-2011. 
Wulandari, N. (2018). Identifikasi Kontrol Diri dan Asertivitas Diri Anggota Geng Sekolah. Jurnal Riset Mahasiswa Bimbingan Dan Konseling, 4(3), 155-165.

Yasdiananda, E. W. (2019). Hubungan antara self esteem dengan asertivitas pada siswa kelas X SMAN 5 Merangin. Jurnal Riset Psikologi, 1(1).

Yuliyanawati, I., Wibowo, M. E., \& Japar, M. (2018). The Effectiveness of Cognitive Behavior Therapy Group Conseling Cognitive with Cognitive Restructuring and Thought Stopping Techniques to Reduce Students Consumptive Behavior. Jurnal Bimbingan Konseling, $7(2), 125-131$. 